YAK 327.8

ББК 66.49

DOI 10.22394/1682-2358-2018-6-22-29

N.B. Pomozova, Candidate of Sciences (Sociology), senior lecturer, Russian State University for the $\mathrm{Hu}$ manities

\section{ON THE HUMAN \\ CAPITAL \\ OF THE MINISTRY \\ OF FOREIGN AFFAIRS \\ OF CHINA \\ (Based on an Analysis \\ of the Biographies \\ of Key Employees \\ from 1998 to 2018)}

In the second half of the 90s China's international policy has entered an active phase. The article considers some biographic features of the key employees of the Ministry of Foreign Affairs of China from 1998 to 2018 as the most important actors of socio-political reflection. The author analyzes three facts of their biographies - the place of birth, the presence or absence of foreign education and work experience outside of China.

Key words and word-combinations: China, biographies of Ministry of Foreign Affairs staff, diplomats, human capital.
Н.Б. Помозова, кандидат соииологических наук, стариий преподаватель Российского государственного гуманитарного университета (email: mpomozova@mail.ru)

\section{О ЧЕАОВЕЧЕСКОМ КАПИТААЕ МИНИСТЕРСТВА ИНОСТРАННЫХ АЕА КИТАЯ (на основе анамиза биографий кАючевыХ сотрУАников в период с 1998 по 2018 г.)}

\footnotetext{
Аннотация. Анализируются причины активизации внешней политики современного Китая, происходящие со второй половины 1990-х годов. Рассматриваются биографии ключевых сотрудников Министерства иностранных дел КНР в период 1998-2018 гг. как важнейших акторов социально-политической рефлексии. Анализируются три факта их биографий: место рождения, наличие или отсутствие зарубежного образования и опыт работы за пределами Китая.

Ключевые слова и словосочетания: Китай, биографии сотрудников МИД, дипломаты, человеческий капитал.
}

$\Pi$ ческого дискурса высшего руководства Китайской Народной Республики на XV-XIX съездах Коммунистической партии Китая (КПК) в период активизаџии межАународной деятельности страны - с конца 1990-х годов до настоящего времени - выявлены характерные особенности [1]. В октябре 1997 г. состоялся XV съезА КПК, где на ос- 
нове анализа международной составляющей доклада Генерального секретаря ЦК КПК Цзян Цзэминя стало понятно, что китайская эмита намерена активно продвигать интересы страны за ее пределами. Важнейшими акторами этой соџиально-политической рефмексии являются кмючевые сотрудники внешнеполитических ведомств, в данном случае - Министерства иностранных дел Китайской Народной Республики (КНР) и Международного отдела Центрального комитета КПК.

Межкународная политика во многом зависит от человеческого капитала [2, с. 138-139] - ^юдей, разрабатывающих стратегию и принимающих решения. Центральные фигуры внешнеполитических ведомств формируют характер и образ мышления, оказывающие непосредственное влияние на их профессиональную деятельность и, следовательно, на вектор межАународной политики страны, на базе своего соџиального бэкграунда - воспитания, образования, опыта, полученного в процессе работы. В случае с сотрудниками Министерства иностранных дел КНР, ответственного за внешнюю политику ведомств Китая, интересным представляется исследование влияния на их профессиональную деятельность опыта, приобретенного в проџессе учебы и работы за гранищей.

Сотрудники Министерства иностранных дел КНР и его зарубежных преАставительств явцяются важнейшими акторами международных отношений, дипломатической службы, представляющей собой, как отмечает Н.В. Аитвак, «специальную службу в системе органов государственной власти, рефмексивный соџиально-политический институт, главным спеџифическим фактором которого явцяется межкультурный характер среды (как в своей, так и в других странах), в которой современные дипмоматические агенты действуют осознанно и цеменаправленно, профессионально рефмексируя, отдавая себе отчет в различиях и динамике культур, интересов, социальных практик, знание которых является Аля них неотъемлемыми условиями профессии, профессиональной деятельности. Это предопределяет необходимость высокого уровня общего и специализированного культурного развития, глубокого знания не только Аругих культур, но и своей собственной, то есть рефмексии и саморефцексии, которые только и позволяют выявцять и понимать сходства и различия культур Аля выполнения профессиональных задач» [3]. Постоянная динамика международной политики, иногда непредсказуемые решения во многом связаны с тем, что сотрудники Министерства иностранных дел КНР вынуждены «конструировать реальность на основе обработки большого массива информации, собранной из все более разнообразных источников, особенно на местах» [4, с. 498] .

Предмет исследования данной публикаџии составцяют биографии сотруАников МИА КНР, занимавших важнейшие посты в период с 1990-х годов до настоящего времени. Анализируются три фактора, оказавшие значительное влияние на становление мичности ведущих работников Министерства иностранных дел Китая: место рождения дипломатов; их высшее образование, полученное в Китае или за его пределами; страны, в которых работали сотрудники МИА, находясь в заграничных командировках. Перечисленные 
факторы - не единственные, воздействуюшие на становление мичности человека и способные повлиять на принятие профессиональных решений, однако данное исследование посвящено именно этим аспектам как наиболее важным с нашей точки зрения. Совокупность знаний и опыта, приобретенных в своей стране и за рубежом, - основа рефлексивных процессов, влияющих на профессиональную деятельность сотрудников ведомства и, как результат, на формирование стратегии внешней политики КНР.

В период, когда Тань Џзясюань возглавмял Министерство иностранных дел Китая (1998-2003), почти половина основных сотрудников (заместители и советники министра) МИА КНР были родом из провинџии Цзянсу. Как и сам министр, абсолютное большинство получили высшее образование исключительно в материковом Китае и мишь один человек - в Гонконге. Более половины дипломатов высшего ранга имели опыт работы в США и странах Западной Европы (рис. 1-3). Опыта работы в России в тот периоА не имел никто из круга приближенных к министру сотрудников ведомства [5; 6] .

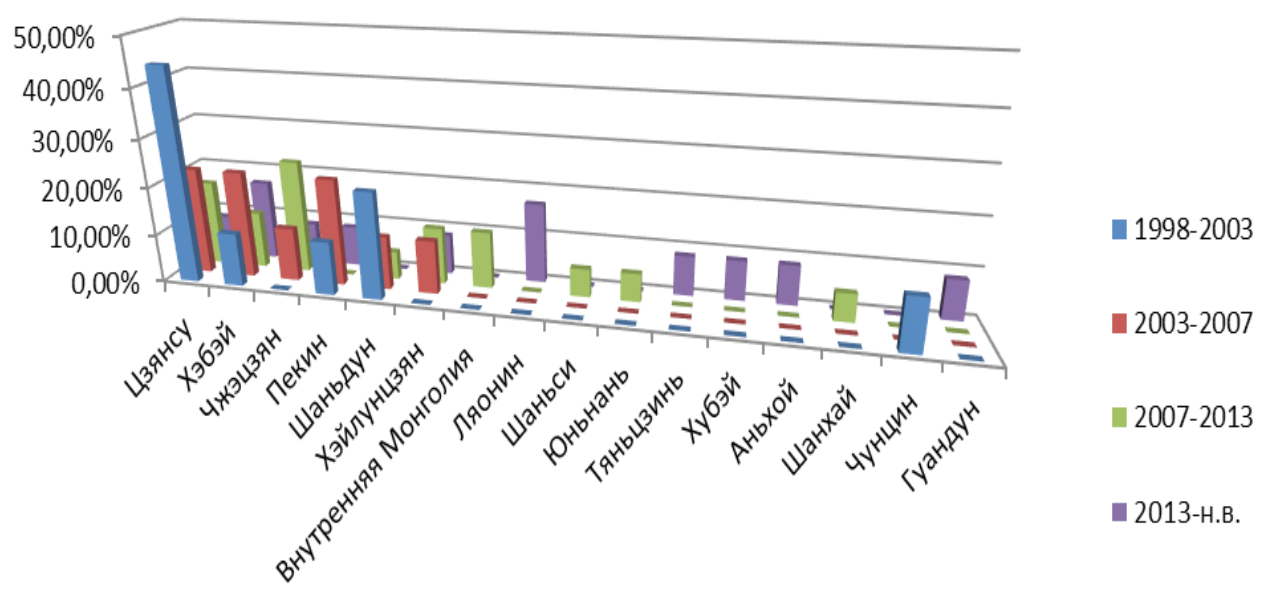

Рис. 1. Место рождения кАючевых сотрудников Министерства иностранных дел Китая в период с 1998 по 2018 г.

С 2003 по 2007 г. МИА КНР возглавлял Аи Чжаосин. Большинство кАючевых работников этого временного отрезка, как и сам $\Lambda$, были уроженцами провинций (Цзянсу и Хэбэй - по 22\%; Чжэџзян, Шаньдун, Хэйкуџзян - по 11\%), закончившими вуз только в Китае. ОАнако по сравнению с предыдущим периодом в руководстве Министерства появляются и те, кто получиц дополнительное образование в Западной Европе и Аатинской Америке, при этом почти половина имема опыт Аипломатической службы в США [5; 6] .

Ян Цзечи, возглавмявший МИА с 2007 по 2013 г., родился в Шанхае и в отличие от своих преАшественников, помимо высшего образования в Китае, закончиц Аондонскую школу экономики. Ведущие сотрудники этого периода 
были родом из различных провинций (самая большая доля - уроженцы провинции Чжәџзян), более половины из них обучались и впоследствии работали в США и странах Западной Европы [5; 6] .

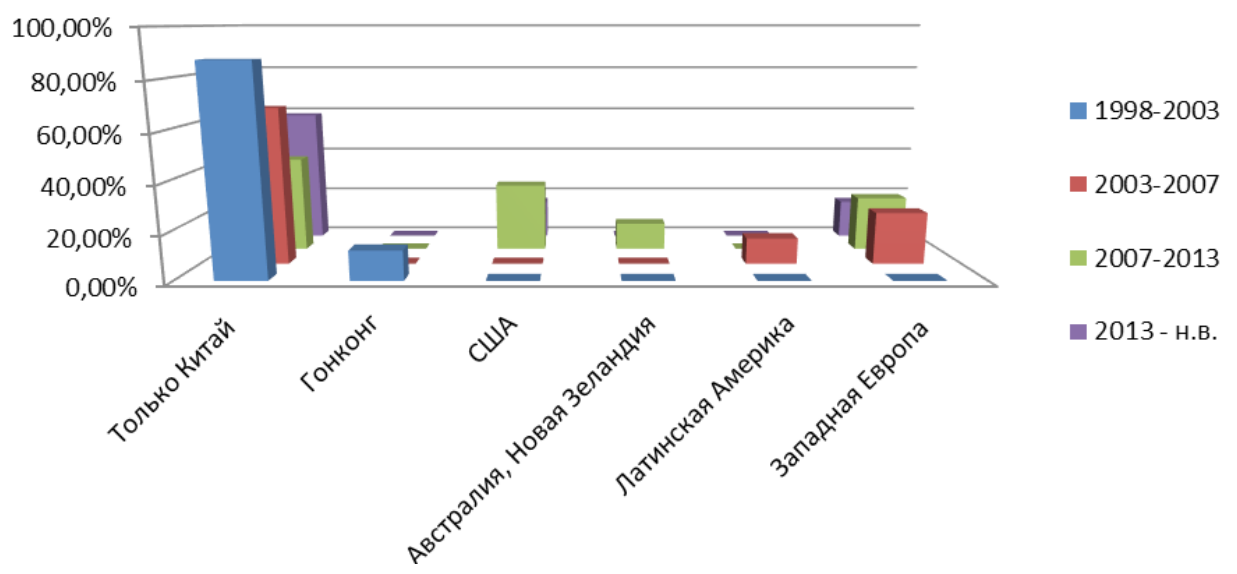

Рис. 2. Высшее образование ключевых сотрудников Министерства иностранных дел Китая в период с 1998 по 2018 г.

Занимающие центральные посты сотрудники МИА в настоящее время традиџионно уроженцы провинций. Большинство получили высшее образование только у себя в стране, в отличие от главы ведомства Ван И, родившегося в Пекине и обучавшегося как на родине, так и в США. В равных долях они занимали руководящие посты зарубежных представительств МИА в странах Западной Европы, США и Азии [5; 6] .

По мнению китайского политолога Жуань Цзунщзе, с 1996 г. начался новый этап в истории межАународной деятельности Китая - «Аипломатия партнерских отношений», который отсчитывается, согласно мнению исследователя, с подписания договора об установлении «партнерских отношений стратегического сотрудничества между Китаем и Россией» [7, с. 296]. Через гоА подобный документ - договор о «конструктивных стратегических партнерских отношениях» был подписан с США. Еше через гоА, в марте 1998 г., Аипцомат Тан Цзясюань, уроженец провинции Цзянсу (как и Председатель КНР Цзян Цзэминь), был назначен восьмым министром иностранных дел Китая. Высшее образование Тан Цзясюань получил на родине, сначала в Фуданьском университете по специальности «Английский язык и культура» (1955-1958), а затем в одном из самых престижных учебных заведений страны - Пекинском университете, по специальности «Восточные языки», где изучал японский язык, что впоследствии определило вектор его дипломатической карьеры. Он занимал различные посты, в том числе значительные, в посольстве КНР в Японии, которая представмяла собой главный противовес нарастающей экономической и военной мощи Китая в Азии. 
Ава заместителя министра иностранных дел - Чжи Пейдинг (19982001) и Аю Гучан (2002-2003), а также помощник министра Ма Цаньжун (1999-2001) - тоже родом из провинции Цзянсу, что вполне вписывается в принцип китайской культуры формировать свой «круг доверенных миџ», назначая заместителями и помощниками тех, с кем вырос, учияся или работал $[5 ; 6]$.

Ни у кого из заместителей Тань Цзясюань нет высшего образования, полученного за рубежком. В середине 1990-х годов Китай только начинает активизаџию межАународной политики после Аолгих мет относительной закрытости, когда все силы были направлены на решение внутренних пробцем, урегумирование спорных территориальных вопросов (Гонконг, Макао, Тайвань), а большинство внешних контактов происходици с бцижайшими соседями и схожими по идеологии государствами. В связи с этим образование за рубежом не приветствовалось, и власти не ставили задачи подготовки кадров за граниџей $[5 ; 6]$.

Статистические данные опыта работы главных сотрудников ведомства в зарубежных преАставительствах МИА Китая в этот период показывают, что по $27 \%$ работали в Европе и США, $18 \%$ - в Азии, $14 \%$ - в Африке и по $5 \%$ - в Австралии, Аатинской Америке и России [8; 9] .

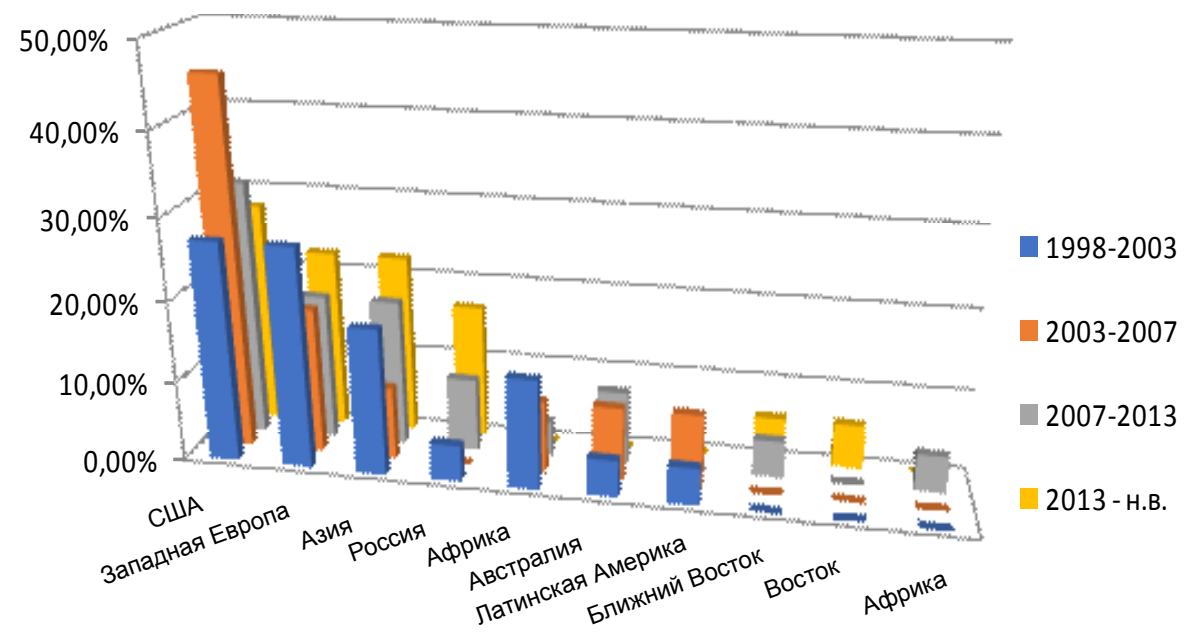

Рис. 3. Опыт работы ключевых сотрудников в зарубежных представительствах Министерства иностранных дем Китая в период с 1998 по 2018 г.

В марте 2003 г. на пост министра иностранных дец быц назначен $\Lambda$ Чжаосин из провинщии Шаньдун, получивший высшее образование в Пекинском университете и в Пекинском университете иностранных языков по специальности «Испанский язык». Начинал он карьеру дипломата в зарубежных преАставительствах МИА КНР в Африке, где занимал разцичные посты. 
В 1985-1990 гг. Аи Чжаосин был заместителем директора, а затем - директором Аепартамента информации и печати. В 1990 г. он стал постоянным представителем и Чрезвычайным и Полномочным Послом КНР в ООН. В 1998 г. Аи Чжаосин занял должность Чрезвычайного и Полномочного Посла КНР в США. В 2001 г., занимая должность заместителя министра иностранных дел, он активно работал с Россией, в частности, возглавил с китайской стороны российско-китайскую группу по борьбе с терроризмом, а в 2002 г. вошел в специальную межправительственную группу по развитию китайскоамериканских отношений.

Таким образом, основные профессиональные интересы $\Lambda$ Чжаосина, занимавшего пост министра иностранных дел КНР с 2003 по 2008 г., находимись в плоскостях китайско-российских и китайско-американских отношений, что вполне отражает тенденцию внешнеполитического вектора КНР в это время [5; 6].

Биографические данные первостепенных сотрудников МИА Китая в пятилетку $\Lambda$ Чжаосина свидетельствуют о том, что большинство из них были уроженцами провинций (по 22\% - Цзянсу и Хэбэй, по $11 \%$ - Чжэџзян, Шаньдун и Хэйлунџзян), а 22\% родились в Пекине. Несмотря на то, что среАи них превалирует Аоля получивших образование только на родине $(67 \%)$, появмяются и те, кто обучался в Великобритании (22\%) [5; 6] .

Аипломатическая карьера $45 \%$ заместителей и помошников министра была связана с США, что на 23\% больше по сравнению с периодом работы ведомства при предыдущем министре. Аоля сотрудников, работавших в Европе, незначительно снизилась и составила $18 \%$. Такая статистика демонстрирует приоритеты внешней политики Китая в этот периоА. На страны Азии, Африки, Аатинской Америки и Австралию пришиось по 9\% [5; 6] .

В апреле 2007 г. новым министром иностранных дел Китая стал уроженец Шанхая Ян Цзечи. Помимо Шанхайского университета иностранных языков, он первый среди своих преАшественников получил образование за гранищей и обучался с 1973 по 1975 г. в Аондонской школе экономики и политических наук. Что касается его профессиональной деятельности, главной домжностью в зарубежном представительстве МИА Китая стала должность посла КНР в США, которую он занимал с 2001 по 2005 г.

КАючевые сотрудники Министерства периода Ян Цзечи были рождены в различных провинщиях (18\% - Цзянсу, 12\% - Хэбэй, 24\% - Чжэџзян, по $12 \%$ - Хэйлунщзян и Внутренняя Монголия и по 6\% - Шаньдун, Шаньси и Юньнань). Аоля заместителей и помощников министра, получивших высшее образование в западных странах, значительно увеличилась по сравнению с периодом $\Lambda$ и Чжаосина и в совокупности составила около $53 \%$ (29\% в США и 24\% - в Западной Европе) от их общего числа.

Около $50 \%$ сотруаников, прежде чем вступить в полномочия руководителей Министерства, занимали верховные посты в зарубежных преАставительствах в странах Запада (32\% - в США, 18\% - в Европе), что на $13 \%$ меньше по сравнению с периодом деятельности предыдущего министра. Опыт работы в Азии, которая по понятным причинам остается важнейшим 
вектором внешней политики Китая имели $18 \%$ заместителей и советников министра. По сравнению с предыдушим периодом появляются $9 \%$ сотрудников с опытом работы в России и странах СНГ [5; 6] .

Аействующий министр иностранных дем Ван И, уроженеу Пекина, был назначен на пост в марте 2013 г. Он окончиц Пекинский Университет иностранных языков по спеџиальности «Японский язык», получиц степень магистра по экономике, а также степень Ph.D. по международным отношениям в Нанкайском университете. Проходия обучение в Университете международных отношений в Ажорджтауне (США), где с 1997 по 1998 г. работал приглашенным ученым Института по изучению дипломатии. Прежде чем возглавить Министерство иностранных дел Китая, занимал ключевые посты в посольстве КНР в Японии.

Все основные сотрудники МИА Китая этого периода были рождены в западных провинџиях страны. Аоля уроженцев Цзянсу постепенно снижалась (от 44,4\% в 1998-2003 гг. Ао 8,3\% в настоящее время), как и родившихся в Шаньдун (22,2\% в 1998-2003 гг., 0\% в настоящее время). В 2013 г. среАи кАючевых сотрудников Министерства иностранных дец появицись те, кто родился в провинциях Аяонин, Хубэй, Аньхой, Гуандун и городе Тяньцинь. Проџент обучавшихся в Европе и США по сравнению с предыдушим периодом остался практически неизменным ( 23 и $29 \%$ соответственно), большинство (58\%) получили высшее образование только у себя в стране. Аоля работавших в странах Западной Европы и США остается высокой (50\%), работавших в Азии и России и странах СНГ - немного увеличивается и составляет 22 и $17 \%$ соответственно [5; 6] .

Итак, на основе анализа биографий кмючевых сотрудников Министерства иностранных дел Китая с конџа 1990-х годов до настоящего времени можно сделать следующие выводы.

Во-первых, большинство заместителей и помощников министра иностранных дел, работавших в ведомстве с 1998 г. были уроженцами не столицы или Аругих крупных городов, прежде всего, Шанхая, а провинций. В первой половине исследуемого периода на значительные должности попадали кадры из восточных провинџий (Цзянсу, Хэбэй, Шаньдун, Чжэџзян). Это связано с тем, что именно в восточной части КНР находятся наиболее крупные, развитые города, где есть больше возможностей получить подготовку Аля того, чтобы потом поступить в столичный вуз. По мере успешной реализации образовательной политики Компартии Китая (в мировом рейтинге ARWU 2003 Китай представлен девятью учебными заведениями [8], а в ARWU 2018 - 51 [9] ) в этой сфере появилось больше возможностей, и, начиная с 2007 г., география происхождения министерского руководства расширилась, в нем появились выходџы из некоторых центральных и южных провинций. Тем не менее численное превосходство осталось за теми, кто был рожден на востоке КНР.

Во-вторых, Аоля сотрудников, обучавшихся только в Китае, хоть и снизимась по сравнению с периодом пятнадџатияетней давности, но все это время (с 1998 по 2018 г.) оставалась неизменно высокой. В первой четверти иссле- 
Ауемого временного промежутка никто из заместителей и помощников министра не проходиц обучение за граниџей, но, начиная с 2003 г., образование в США и странах Западной Европы (преимушественно в Мондоне) стало признаком тех, кто назначался в руководство МИА КНР, при этом западное образование всегда шло в Аополнение к основному высшему образованию, полученному на родине.

В-третьих, процент основных руководителей МИА Китая, работавших по Аипломатической кинии в США и Западной Европе, на протяжении всего исследуемого периода быц стабицьно высоким - их большинство по сравнению со спещиалистами, получившими опыт работы в Аругих зарубежных странах. Аоля находившихся в загранкомандировке в России и странах СНГ к настоящему времени увеличилась в три раза по сравнению с периодом с 1998 по 2003 г.

Незначительно возросло количество тех, кто имеет опыт работы в странах Азии. К 2013 г. (в отличие от предылущих периодов исследования) среАи кцючевых сотрудников Министерства иностранных дел Китая не осталось тех, кто работац в странах Африки, Аатинской Америки, Австрации и Новой Зеландии.

Это свидетельствует о Аинамике расстановки акцентов внешнеполитического курса Китая, где приоритетными направлениями остаются США и Западная Европа, страны Азии, а также Россия. Рефлексия западных реамий специфически накцадывается на фундаментальные знания, полученные в Китае, и Аополнительно вцияет на определение внешнеполитического кypca.

\section{Библиографический список}

1. Помозова Н.Б. Отражение внешнеполитического вектора в дискурсе докладов на XV-XIX съездах Коммунистической партии Китая // Государственное и муниципальное управление. Ученые записки. 2018. № 6.

2. Литвак Н.В. Экономический и информационный подходы к определению «человеческого капитала» // Вестник МГИМО-Университета. 2013. № 3.

3. Литвак Н.В. Современная дипломатическая служба как рефлексивный институт // Полис. 2018. № 2. С. 163-172.

4. Piotet F., Loriol M., Delfolie D. 2013. Splendeus et miseres du travail des diplomates. Paris, 2013.

5. Официальный сайт Министерства иностранных дел KHP. URL: https://www.fmprc.gov.cn

6. Электронная база данных биографий официальных лиц KHP. URL: http://www.chinavitae.com

7. Грачиков E.H. Внешняя политика Китая: стратегии в контексте идентичности и глобальной перспективы // Международные отношения. 2015. № 3.

8. Официальный сайт международного академического рейтинга высших учебных заведений. URL: http://www.shanghairanking.com/ARWU2003.html

9. Официальный сайт международного академического рейтинга высших учебных заведений. URL: http://www.shanghairanking.com/World-University-Rankings-2018/China. html 